\title{
The Distribution of Intestinal Amoebae in Wild Long-Tailed Macaques (Macaca fascicularis) in Sabang City, Aceh Province, Indonesia
}

\author{
Junaidi $^{1,2}$, Umi Cahyaningsih ${ }^{1, *}$, Trioso Purnawarman ${ }^{1}$, Hadri Latif $^{1}$, \\ Etih Sudarnika ${ }^{1}$ Farida $^{3}$ and Maryatun ${ }^{4}$ \\ ${ }^{I}$ Department of Animal Disease and Veterinary Public Health, Faculty of Veterinary Medicine, Bogor \\ Agricultural University, Bogor, Indonesia \\ ${ }^{2}$ Public Health study program the Institute of Health Science of Abdi Nusa, Pangkalpinang, Bangka \\ Belitung Islands, Indonesia \\ ${ }^{3}$ Parasitology Laboratory at the Faculty Veterinary Medicine of Syiah Kuala University, Aceh, Indonesia \\ ${ }^{4}$ Parasitology Division Faculty of Medicine and dr. Zainoel Abidin Hospital Banda Aceh of Syiah Kuala \\ University, Aceh, Indonesia
}

('Corresponding author's e-mail: umicahyaningsih@yahoo.co.id, umi-ch@apps.ipb.ac.id)

Received: 19 August 2020, Revised: 9 April 2021, Accepted: 19 May 2021

\begin{abstract}
Amoeba that infects primates can also be found in humans and can be zoonotic. This study aims to identify the distribution of intestinal amoeba in the wild Long-Tailed Macaque (LTM) group located at Cot Murong, Kebun Mangga, and Tugu Zero Kilometer Monument (IZKM) in Sabang City, Aceh Province, Indonesia. A total of 177 stool samples from 59 tails from the three LTM groups were examined microscopically. The results of the examination confirmed seven species of intestinal amoeba, three of which belonged to the genus Entamoeba, namely the Entamoeba histolytica/dispar/moshkovskii complex, Entamoeba coli, Entamoeba pölecki, and four other species from different genera, namely Iodamoeba butschlii, Blastocystis sp., Endolimax nana and Dientamoeba fragilis. The prevalence of intestinal amoeba in wild LTM in Sabang City was 57.6\% (102/177). Dientamoeba fragilis was only found in the LTM group of Kebun Mangga. Entamoeba coli dominated the highest prevalence in all LTM groups. The LTM group located around Cot Murong and IZKM had a higher concentration of infection with intestinal amoeba than the Kebun Mangga location. The statistical tests showed a significant difference between the proportions of Iodamoeba butschlii, Endolimax nana and Dientamoeba fragilis, both found in the LTM Cot Murong, Kebun Mangga, or IZKM groups. This study is the first to report amoebic infection prevalence in the wild LTM group in Sabang City, Aceh Province. The pathogenic amoeba that cannot be distinguished microscopically from morphologically identical amoebae needs to be identified molecularly to identify variants and their potential as zoonotic agents.
\end{abstract}

Keywords: Prevalence, Intestinal amoebae, Macaca fascicularis, Aceh Province, Indonesia

\section{Introduction}

The long-tailed macaque (Macaca fascicularis) is a species of primates that live in groups in the forests, riverbanks, seasides and sometimes around human settlements [1-2]. These unprotected animals play an essential role in transmitting various types of parasites to humans [3]. A species of endoparasites that is often overlooked by transmission to humans is an amoebae.

Amoebae is a unicellular organism that lives in water and soil. Some of them are commensal parasites [31]. While the others are pathogens in humans, primates, birds, reptiles, and several other mammals potentially zoonotic, which can cause disease in animals and transmit to humans or vice versa [4-32]. One of the amoeba pathogens in humans and primates is Entamoeba histolytica (E. histolytica) [5]. The amoeba that causes amoebiasis infects 40-50 million people every year. About $40-100$ thousand of them end in death [6]. Apart from E. histolytica, other non-pathogenic amoebae can parasitize humans and primates, such as Entamoeba dispar (E. dispar), Entamoeba moshkovskii (E. moshkovskii), Entamoeba pölecki (E. pölecki), Entamoeba nutalli (E. nutalli), Entamoeba chattoni (E. chattoni), Entamoeba coli (E. coli), Entamoeba hartmanni (E. hartmanni), Entamoeba ecuadoriensis (E. ecuadoriensis), E. nana (Endolimax nana), Iodamoeba butschlii (I. butschlii), Blastocytis sp and Dientamoeba fragilis (D. fragilis) [7-8]. Although some species of amoebae are not dangerous, their 
presence in vulnerable groups such as infants and children, the elderly, people with HIV AIDS and other immunocompromised people, is often associated with the incidence of non-specific diarrhea and other digestive disorders [9].

Distinguishing amoebic species based on differences in cell morphology is a challenge in microscopic examination. This is because several amoebic species such as E. histolytica with E. dispar, or E. moshkovskii have identical morphological features, so the results of this identification must be confirmed by other identification techniques [21]. However, if not endorsed by other identification techniques, the results of the title of the 3 species are reported as E. histolytica/dispar/moshkovskii complex [22].

Sabang City, a city located in the outer islands of the western tip of Indonesia, has protected and conservation forests. The existence of these forest areas makes it possible to grow and reproduce various wild animals. One of the endemic wildlife of Sabang City is the long-tailed macaques that often come down to residential areas and tourist attractions. The interaction of these long-tailed macaques with humans can cause various unwanted effects, and one of these impacts is the spread of intestinal amoebae to the environment. The spread of intestinal amoebae in the environment originating from primates, especially macaques, has not been widely informed, so there is no specific policy regulating the prevention of the spread of intestinal amoebae originating from primate animals. The purpose of the study was to evaluate the distribution of intestinal amoebae in groups of wild macaques around residential areas and tourist attractions centers in Sabang City, Aceh Province, Indonesia.

\section{Materials and methods}

\section{Study area and research subjects}

Sabang City is located at the western tip of the archipelago, which is the Point of Zero Kilometer of the Republic of Indonesia. Sabang City area is at 95 $13^{\prime} 02$ " $-95^{\circ} 22^{\prime} 36^{\prime \prime}$ east longitude and $05^{\circ} 46^{\prime} 28$ "$05^{\circ} 54^{\prime}-28^{\prime \prime}$ north latitude, is the northernmost administrative area of Indonesia, and directly borders with neighboring countries. Namely Malaysia, Thailand and India. Administratively, Sabang City has brick boundaries, namely the northern and eastern borders with the Malacca Strait, in the south bordering the Bengal Strait and west bordered by the Indonesian Ocean.

Long-tailed macaques are primates of the Cercopithecoidea family that are characterized by a longtail that almost always exceeds the length of their head and body [14]. Macaques' sex and age were identified based on observations of the characteristics and behaviors. Sex differences are distinguished by whether or not the testicles or penis is visible. The infant group characterized by a tiny body size, dark black hair, more often attached to the mother's body, and still being breastfed. The yearling macaques were characterized by changes in fur resembling that of adult macaques, larger body size than babies, very agile but always under the supervision of the mother. The juvenile macaques' group was characterized by a larger body size than the children, very agile, often competing with adult macaques, unable or rarely to copulate. Adult macaques were characterized by their large body size, visible secondary features such as mustaches and beards.

\section{Ethical approval and inclusion criteria}

This research is an epidemiological survey research using a cross-sectional design. This study has received ethical approval from the Health Service Ethics Committee of the Medical Faculty of Syiah Kuala University and dr. Zainoel Abidin Hospital in Banda Aceh Number: 149/EA/FK-RSUZA/2019. The subjects in this study had met the inclusion and exclusion criteria. The inclusion criterion of this research is a group of macaques that frequently interacts with almost every day humans, are located in 1 area, can be habituated, and can be observed. The macaques living outside the study site were the exclusion criteria for research subjects. The study collected 59 macaques distributed in 3 different locations: 17 in Cot Murong location, 19 in Kebun Mangga and 23 in the Zero Kilometer Monument (IZKM). Identification of sex and age of individual macaques and groups was performed using a concentration count technique [10]. The location data for the research sample was obtained from the results of coordinates marking using the Global Positioning System (GPS).

\section{Procedures}

Stool samples from the macaques group were taken 3 times on different days for 10 days [11]. A total of 177 stool samples that fell to the ground were taken with a spoon and pot aseptically. The jars were sealed, labeled, and put in a cool box to be taken to temporary storage after collection. The samples were transferred to a refrigerator at a temperature of minus $4{ }^{\circ} \mathrm{C}$. After the samples were collected. All 
samples were moved back into the cold box and transported to the parasitology laboratory of the Faculty of Veterinary Medicine, Syiah Kuala University, Banda Aceh, Indonesia.

Intestinal amoebic parasitic data in the wild MEP group were obtained from the microscopic examination of their stool samples. Fresh wild MEP stool samples were randomly taken under the treehouse where their group lived. To estimate how many individuals from each of the wild MEP groups parasitized by intestinal amoebae, a pile of feces was taken by several individuals living together in the group and collected in unique pots. To make sure the amoebae exists, this sampling is repeated 3 times on different days. The examination is positive if the identification of samples taken on the $1^{\text {st }}, 2^{\text {nd }}$ and $3^{\text {rd }}$ day of $1,2^{\text {nd }}$, or all 3 are found to be amoebae.

Examination of the sample begins with screening positive samples of intestinal amoebae using the wet mount, deposition and flotation techniques [12]. Positive samples were found in one of these techniques, then stained with Wheatley's trichrome staining technique [13]. The characteristics of the amoebic cells were identified using the Olympus Binocular CX 23 Microscope and Dino-Lite Series AM4025X digital camera microscope.

\section{Data analysis}

The research data were analyzed using descriptive statistics and inferential statistics with Microsoft Excel 2013(C), Statistical Package for the Social Sciences (SPSS) Version 26 and Quantum GIS Desktop 3.4.15. Proportion, prevalence, and distribution of amoebae data are presented descriptively in tables, graphs and heatmap formats. Data on differences in the proportion of amoebae in each group of research subjects were analyzed using the Chi-Square K-Sample test with a significance level of $5 \%$.

\section{Results and discussion}

\section{Frequency distribution of wild long-tailed macaque}

The frequency distribution of macaques in the 3 study locations shows that the macaque group around IZKM had more group members ( 23 or $39 \%$ ) than the other 2 groups. Of the 3 groups, macaques around Cot Murong had a higher proportion of females and yearling macaques than the other 2 groups (Table 1).

Table 1 Frequency distribution of wild long-tailed macaque at the 3 study sites.

\begin{tabular}{lccccccc}
\hline \multirow{2}{*}{$\begin{array}{c}\text { Location of wild } \\
\text { macaque } \\
\text { group }\end{array}$} & $\begin{array}{c}\text { Male } \\
\mathbf{n ~ ( \% )}\end{array}$ & $\begin{array}{c}\text { Female } \\
\mathbf{n}(\%)\end{array}$ & $\begin{array}{c}\text { Sex } \\
\text { identified n } \\
(\mathbf{\%}) *\end{array}$ & $\begin{array}{c}\text { Adult and } \\
\text { adolescent } \\
\mathbf{n}(\%)\end{array}$ & $\begin{array}{c}\text { Kids } \\
\mathbf{n}(\%)\end{array}$ & $\begin{array}{c}\text { Infants } \\
\mathbf{n}(\%)\end{array}$ & $\begin{array}{c}\text { Total } \\
\mathbf{n}(\%)\end{array}$ \\
\hline Cot Murong & $5(28.8)$ & $9(53.8)$ & $3(17.6)$ & $8(47.1)$ & $6(35.3)$ & $3(17.6)$ & $17(28.8)$ \\
Kebun Mangga & $7(39.4)$ & $8(39.5)$ & $4(21.1)$ & $12(63.2)$ & $4(21.1)$ & $3(15.8)$ & $19(32.2)$ \\
IZKM & $9(39.2)$ & $10(43.4)$ & $4(17.4)$ & $11(47.8)$ & $7(30.5)$ & $5(21.7)$ & $23(39.0)$ \\
Total & $24(40.7)$ & $25(42.4)$ & $10(16.9)$ & $31(52.6)$ & $17(28.8)$ & $11(18.6)$ & $59(100.0)$ \\
\hline
\end{tabular}

* Baby macaques are very small in size and are permanently attached to the mother's stomach so that they cannot see the penis or scrotum.

\section{Prevalence of intestinal amoebae in wild long-tailed macaque group in Sabang City, Aceh} Province

Based on Table 2, it can be seen that in 57.6\% (102/177) samples found various species of intestinal amoeba, and based on the results of cell morphology identification, 10.7\% (19/177) cells were verified as Entamoeba histolytica/dispar/moshkovski complex, 23.2\% (41/177) of amoebic cells identified as E. coli, $18.6 \%$ (33/177) cells verified as E. pölecki, 7.9\% (14/177) cells verified as $I$. butschli, 3.4\% (6/177) cells were verified as D. fragilis, and 6.2\% (11/177) cells were verified as Blastocystis sp. Based on the pattern, the combination of amoeba species from $E$. coli species with $E$. pölecki being the most common species combination found in the amount of 5.6\% (10/177) samples. While the combination of E. pölecki with Blastocytis sp. and the Entamoeba histolytica/dispar/moshkovski complex with E. nana being the least detected amoeba species, with only one sample (06/177) each combination.

The same study previously did not report findings of intestinal amoeba, which is one of the variables in the study of intestinal parasites in wild LTM in tourist sites in Sabang City [16]. In another study in Indonesia, the prevalence could reach 40\% [17]. These two data are very different from the results of this study and show the same pattern as the research conducted in China [30]. Most of the 
samples examined in this study were found to be various species of intestinal amoeba, and amoeba species from $E$. coli species dominated the prevalence of infection. Besides that, given the amoebic parasites that can occur at any time, differences in climate, inspection techniques and time ranges, maybe the factors causing these differences [23-26].

Table 2 Frequency distribution of intestinal amoebae in the wild long-tailed macaque group in Sabang City, Aceh Province in 2020.

\begin{tabular}{|c|c|c|}
\hline Amoeba species and infection pattern & $\begin{array}{l}\text { The number of samples be } \\
\text { examined }(N=177)\end{array}$ & Percentage \\
\hline Intestinal Amoeba & 102 & 57,6 \\
\hline Single (one species of amoeba) & 65 & 36,7 \\
\hline Entamoeba histolytica/dispar/moshkovski complex & 19 & 10,7 \\
\hline E. coli & 41 & 23,2 \\
\hline E. pölecki & 33 & 18,6 \\
\hline I.butschli & 14 & 7,9 \\
\hline E. nana & 17 & 9,6 \\
\hline D. fragilis & 6 & 3,4 \\
\hline Blastocystis sp. & 11 & 6,2 \\
\hline Multi (more than one species of amoeba) & 37 & 20,9 \\
\hline E. coli with $E$. polecki & 10 & 5,6 \\
\hline $\begin{array}{l}\text { Entamoeba histolytica/dispar/moshkovski complex with } \\
\text { E. coli }\end{array}$ & 5 & 2,8 \\
\hline E. coli with I. butschli & 2 & 1,1 \\
\hline $\begin{array}{l}\text { Entamoeba histolytica/dispar/moshkovski complex with } \\
\text { D. fragilis }\end{array}$ & 6 & 1,4 \\
\hline E. coli with Blastocytis sp. & 2 & 1,1 \\
\hline E. coli with E. nana & 4 & 2,3 \\
\hline $\begin{array}{l}\text { E. pölecki with Entamoeba histolytica/dispar/moshkovski } \\
\text { complex }\end{array}$ & 5 & 2.8 \\
\hline E. pölecki with I.butschli & 2 & 1,1 \\
\hline E. pölecki with Blastocytis sp. & 1 & 0,6 \\
\hline E. pölecki with E. nana & 3 & 1,7 \\
\hline $\begin{array}{l}\text { Entamoeba histolytica/dispar/moshkovski complex with } \\
\text { Blastocytis } \mathrm{sp} .\end{array}$ & 3 & 1,7 \\
\hline $\begin{array}{l}\text { Entamoeba histolytica/dispar/moshkovski complex with } \\
\text { E. nana }\end{array}$ & 1 & 0,6 \\
\hline
\end{tabular}

Based on Table 3, it can be seen that the wild LTM group around Cot Murong had a higher percentage of infection with intestinal amoeba compared to the other two wild LTM groups. The same thing was also shown from the proportion analysis where at the 95\% Confidence Interval (CI) the proportion of intestinal amoeba in the LTM Cot Murong group was different from the proportion of intestinal amoeba found in the IZKM and Kebun Mangga. The immune system is related to age and sex [15]. Infants, children, the elderly, pregnant and lactating age groups are usually more susceptible to illness associated with infectious diseases. Given that the composition of LTM around Cot Murong is more in the age group of children and females, the high prevalence of intestinal amoeba in that group may be correlated with age and sex factors.

Table 3 Frequency distribution of intestinal amoeba in wild long-tailed macaque (LTM) groups based on sampling locations.

\begin{tabular}{lccc}
\hline $\begin{array}{c}\text { Wild LTM } \\
\text { locations }\end{array}$ & n (+) intestinal amoeba (\%) & Confidence Interval (CL) 95\% & Total \\
\hline Cot Murong & $34(66,7)$ & $94,2-100$ & 51 \\
Kebun Mangga & $27(47,4)$ & $50,6-75,7$ & 57 \\
IZKM & $41(59,4)$ & $71,9-90,4$ & 69 \\
Total & $118(57,6)$ & $74,4-86,1$ & 177 \\
\hline
\end{tabular}


Based on Figure 1, it can be seen that the prevalence of non-pathogenic amoeba, namely E. coli and E. pölecki, dominated the highest percentage in all LTM groups. Meanwhile, the amoeba of the $D$. fragilis species was the lowest prevalence and was only found in the LTM group in the Cot Murong location.

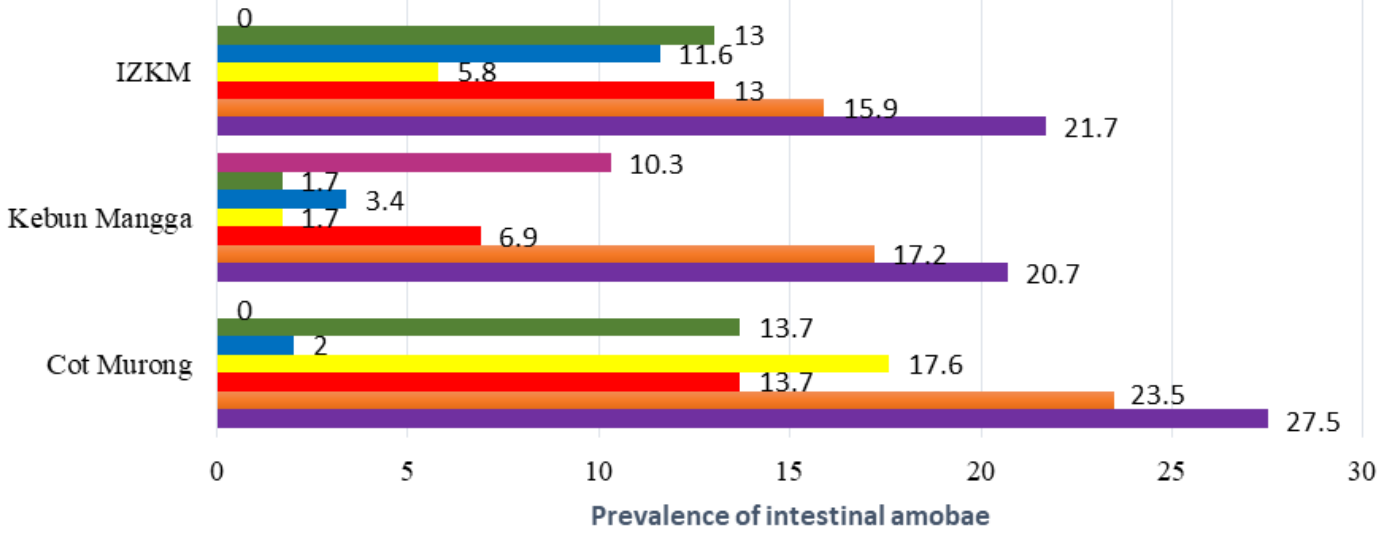

$\square$ D. Fragilis $\square$ E. nana Blastocytis sp. I. bütschlii $\square$ Entamoeba histolytica / dispar / moshkovskii $\square$ E. pölecki $\square$. coli

Figure 1 Graph of intestinal amoebae prevalence in the wild long-tailed macaque group in Sabang City, Aceh Province.

E. histolytica and D. fragilis infections are frequent health problems. E. histolytica is the only causative agent for amoebiasis. Their invasion in the intestinal wall causes hemorrhagic dysentery, colitis. In advanced cases, parasites can invade other organs such as the peritoneum, liver, lungs, heart, kidneys, brain, which can be fatal [18]. D. fragilis infection can also cause gastrointestinal disturbances. The clinical presentation of amoebic disease varies, from asymptomatic to mild and moderate symptoms. Infected individuals usually experience changes in bowel movements, abdominal discomfort, nausea and diarrhea [19]. Apart from E. histolytica and D. fragilis, the amoebae that parasitize the Sabang City macaques group are non-pathogenic. However, their presence must be watched out because it can act as a co-infection against other pathogenic agents [20].

\section{Spread of intestinal amoebae in the wild long-tailed macaque group in Sabang City, Aceh} Province

The color concentration in the heat map illustrates the concentration of intestinal amoebae in the location of the wild long-tailed macaque group of Sabang City. The long-tailed macaque in the Cot Murong location and the IZKM appeared more concentrated in intestinal amoebae than the long-tailed macaque at the Kebun Mangga location (Figure 2). This indicates that the location of Cot Murong and IZKM have ideal environmental aspects that allow amoebae to parasitize long-tailed macaque more easily.

Cot Murong and IZKM have almost the same characteristics, namely locations that are crowded with people because these locations are the roads to tourist objects and tourist objects of IZKM. The longtailed macaque is in these locations interacted more frequently with humans than those in Kebun Mangga locations. The long-tailed macaque that lives side by side with humans will be easily infected with human-originating infectious diseases or vice versa [25]. The long-tailed macaque food-seeking behavior from human waste, the relationship between individuals and groups, may be the trigger for amoebae being concentrated in the Cot Murong long-tailed macaque's and IZKM. 

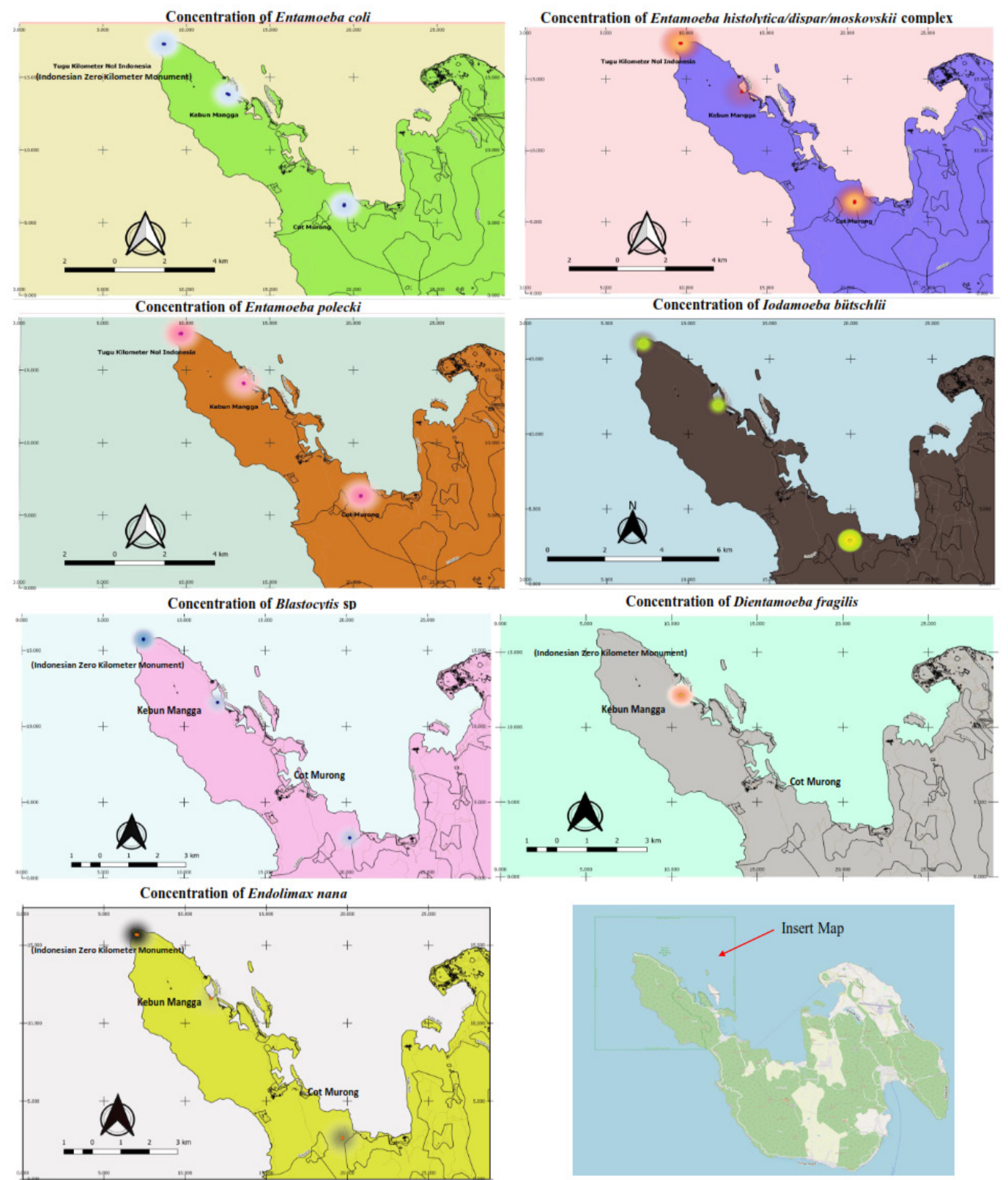

Figure 2 Intestinal amoebae concentration map in the wild macaques' group in Sabang City, Aceh Province.

\section{Conclusions}

The prevalence of intestinal amoeba in the wild macaque group in Sabang City, Aceh Province, is high. Most of the identified amoebae are non-pathogenic amoebae. E. histolytica, as the causative agent for amoebiasis, was found in all groups of macaques. In contrast, D. fragilis, the causative agent for dientamoebiasis, was only detected in the Kebun Mangga location. The location of the macaques around Cot Murong and IZKM concentrated most types of intestinal amoeba. There were differences in the proportion of intestinal amoebae of the species D. fragilis, E. nana and I. butschlii with the locations of macaques around Cot Murong, Kebun Mangga and IZKM.

It is necessary to limit the interaction between humans and primates, especially wild long-tailed macaque group in Sabang City. Restriction can be done by improving primary forests to have sufficient habitat and food in the forest. This condition can prevent the wild long-tailed macaque group from infiltrating residential areas. There needs to be education for tourists visiting the Sabang City area so that 
they do not provide food to the wild long-tailed macaque group because it will allow them to become accustomed to interacting with humans.

The community and tourists around the wild macaques' location always pay attention to hygiene and sanitation aspects such as washing hands with running water and soap, not bringing or eating at the wild macaques' location. The community or tourists need to be educated so they do not provide food to wild macaques' because it will give wild macaques' the opportunity to become accustomed to interacting with humans. The government needs to pay special attention to wild macaques' existence by limiting interactions between wild macaques' and humans. It is necessary to identify at the molecular level of 3 Entamoeba species that have identical morphology to differentiate between pathogenic E. histolytica and other non-pathogenic, namely, E. dispar and E. moshkovskii. It is necessary to explore amoebae's phylogenetic aspects to provide information about its relationship with human isolates.

\section{Acknowledgements}

The authors thank the Ministry of Research, Technology and Higher Education (Kemenristek Dikti), Indonesia, for funding this research through the Indonesia-Domestic Lecturer Excellence Scholarship (BUDI-DN).

\section{References}

[1] C Roos, R Boonratana, J Supriatna, J Fellowes, C Groves, S Nash, A Rylands and R Mittermeier. An updated taxonomy and conservation status review of Asian primates. Asian Primates J. 2014; 4, $2-38$.

[2] JA Joesoef, D Sajuthi, A Wijaya and MUE Sanam. Endoparasitic diversity in Macaca fascicularis and its zoonotic potential on different weather in Kupang City (in Indonesian). J. Vet. 2018; 19, 451-9.

[3] TL Goldberg, A Gendron-Fitzpatrick, KM Deering, RS Wallace, VL Clyde, M Lauck, GE Rosen, AJ Bennett, EC Greiner and DH O'Connor. Fatal metacestode infection in Bornean orangutan caused by unknown Versteria species. Emerg. Infect. Dis. 2014; 20, 109-13.

[4] N Yoshida, KM Tyler and MS Llewellyn. Invasion mechanisms among emerging food-borne protozoan parasites. Trends Parasit. 2011; 27, 459-66.

[5] B Sebastien. Autophagy in parasitic protists. In: MA Hayat (Ed.). Autophagy: Cancer, other pathologies, inflammation, immunity, infection, and aging. $2^{\text {nd }}$ eds. New Jersey, 2014, p. 185-95.

[6] World Health Organization. Weekly Epidemiological Record, Available at: https://apps.who.Int/iris/handle/10665/230102, accessed July 2019.

[7] C Church, A Neill and AM Schotthoefer. Intestinal infections in humans in the Rocky Mountain Region, United States. J. Parasitol. 2010; 96, 194-6.

[8] LJ Ragazzo, S Zohdy, M Velonabison, J Herrera, PC Wright and TR Gillespie. Entamoeba histolytica infection in wild lemurs associated with proximity to humans. Vet. Parasitol. 2018; 249, 98-101.

[9] A Hussain, EZ Younis, AH Elamami, M Jelodar, T Mishra and G Shivaramaiah. Prevalence of intestinal parasitic infestation among expatriate workers. Cureus 2019; 11, e4894.

[10] GH Volpato, EV Lopes, LB Mendonca, R Bocon, MV Bisheimer, PP Serafini and AD Luiz. The use of the point count method for bird survey in the Atlantic forest. Zoologia 2009; 26, 74-8.

[11] AJ Showler and AK Boggild. Entamoeba histolytica. Can. Med. Assoc. J. 2013; 185, 1064.

[12] AK Santosh. Microbiological stool examination: Overview. J. Clin. Diagn. Res. 2012; 6, 503-9.

[13] Thermo Fisher Scientific. Remel Wheatley Trichrome Stain [manual procedure], Available at: https://www.thermofisher.com/search/results?query=\%20Wheatley\%20Trichrome\%20Stain\&perso na=DocSupport, accessed October 2019.

[14] CK Lang. Long-tailed macaque (Macaca fascicularis), Available at: http://pin.primate.wisc.edu/factsheets/entry/long-tailed_macaque, accessed September 2019.

[15] AK Simon, GA Hollander and A Mcmichael. Evolution of the immune system in humans from infancy to old age. Proc. Biol. Sci. 2015; 282, 20143085.

[16] E Rahmi, M Hanafiah, A Sutriana, M Hambal and F Wajidi. The Incidence of gastrointestinal parasite in wild long tail macaque in wildlife reserve park, Weh Island, Sabang (in Indonesian). $J$. Indones. Anim. Sci. 2010; 13, 289-91.

[17] AAWK Putra, IN Wandia and IM Dwinata. Prevalence and identification of gastrointestinal protozoa in longtail macaque in Nusa Penida Island (in Indonesian). Bul. Vet. Udayana 2020; 12, 80-9. 
[18] S Ghosh, J Padalia and S Moonah. Tissue destruction caused by Entamoeba histolytica parasite: Cell death, inflammation, invasion, and the gut microbiome. Curr. Clin. Microbiol. Rep. 2019; 6, 51-7.

[19] N Nagata, D Marriott, J Harkness, JT Ellis and D Stark. Current treatment options for Dientamoeba fragilis infections. Int. J. Parasitol. Drugs Drug Resist. 2012; 2, 204-15.

[20] T Ji, HX Cao, R Wu, LL Cui, GM Su, C Niu, N Zhang, SK Wang and DH Zhou. Prevalence and genetic identification of three Entamoeba species in pigs in Southeastern China. BioMed Res. Int. 2019; 2019, 2824017.

[21] P Nowak, K Mastalska and J Loster. Entamoeba histolytica - pathogenic protozoan of the large intestine in humans. J. Clin. Microbiol. Biochem. Technol. 2015; 1, 10-7.

[22] NM Soares, HC Azevedo, FTP Pacheco, JN De Souza, RP Del-Rei, MCA Teixeira, and FLN Santos. A cross-sectional study of Entamoeba histolytica/dispar/moshkovskii complex in Salvador, Bahia, Brazil. BioMed Res. Int. 2019; 2019, 7523670.

[23] V Khanna, K Tilak, S Rasheed and C Mukhopadhyay. Identification and preservation of intestinal parasites using methylene blue-glycerol mount: A new approach to stool microscopy. J. Parasitol. Res. 2014; 2014, 672018.

[24] CA Chapman, DD Bowman, RR Ghai, JF Gogarten, TL Goldberg, JM Rothman, D Twinomugisha and $\mathrm{C}$ Walsh. Protozoan parasites in group-living primates: Testing the biological island hypothesis. Am. J. Primatol. 2012; 74, 510-7.

[25] X Zhang, KA Kadir, LF Quintanilla-Zarinan, J Villano, P Houghton, H Du, B Singh and DG Smith. Distribution and prevalence of malaria parasites among long-tailed macaques (Macaca fascicularis) in regional populations across Southeast Asia. Malar. J. 2016; 15, 450.

[26] T Day, AL Graham and AF Read. Evolution of parasite virulence when host responses cause disease. Proc. Biol. Sci. 2007; 274, 2685-92.

[27] M Muller, M Mentel, JJ Hellemond, K Henze, C Woehle, SB Gould, RY Yu, M Giezen, AGM Tielens and WF Martin. Biochemistry and evolution of anaerobic energy metabolism in eukaryotes. Microbiol. Mol. Biol. Rev. 2012; 76, 444-95.

[28] R Subahar and L Sutanto. Ascaris lumbricoides eggs and human-intestinal protozoan cysts found in river water of Angke river, Jakarta. Makara Kes. 2008; 12, 83-5.

[29] GT El-Sherbini and MR Gneidy. Cockroaches and flies in mechanical transmission of medical important parasites in Khaldyia Village, El-Fayoum, Governorate, Egypt. J. Egypt. Soc. Parasitol. 2012; 42, 165-74.

[30] M Feng, B Yang, L Yang, Y Fu, Y Zhuang, L Liang, Q Xu, X Cheng and H Tachibana. High prevalence of Entamoeba infections in captive long-tailed macaques in China. Parasitol. Res. 2021; 4, 1093-97.

[31] R Issa. Non-pathogenic protozoa (review article). Int. J. Pharm. Pharm. Sci. 2014; 3, 30-40.

[32] S Kumar, P Sundararaj, HN Kumara, A Pal, K Santhosh and S Vinoth. Prevalence of gastrointestinal parasites in bonnet macaque and possible consequences of their unmanaged relocations. PLoS One 2018; 11, 1-23. 